\title{
ENSURING OPERATIONAL RELIABILITY OF OVERPASS ON "ALMATY-KAPSHAGAI" HIGHWAY SECTION IN KAZAKHSTAN
}

\author{
Assylkhan Jalairov', Dauren Kumar ${ }^{2, *}$, Khaini-Kamal Kassymkanova², Gulshat Murzalina ${ }^{3}$, Gulnar Jangulova ${ }^{2}$ \\ ${ }^{1}$ Department of Transport, Construction, Bridges and Tunnels, Kazakh University of Way Transport, Almaty, \\ Republic of Kazakhstan \\ ${ }^{2}$ Department of Cartography and Geoinformatics, Al-Farabi Kazakh National University, Almaty, Republic \\ of Kazakhstan \\ ${ }^{3}$ Faculty of General Construction, International Education Corporation, Almaty, Republic of Kazakhstan
}

*E-mail of corresponding author: daurendkb@gmail.com

\section{Resume}

The article presents results of the overpass condition survey, technical survey, static tests and assessment of the structure operational reliability, a doubledecker overpass on Almaty-Kapshagai highway section in Kazakhstan. Technical survey determined the dimensions of the overpass, the camber of reinforced concrete superstructures main beams and checked the values of the overpass roadway actual transverse and longitudinal slopes. The calculation and analytical assessment of the overpass load-bearing structures, for the strength of the bending moment, are performed. Static tests of the overpass split beam superstructure of a length of $33.0 \mathrm{~m}$ were conducted. Trucks loaded with ballast were accepted as a test load.

Available online: https://doi.org/10.26552/com.C.2022.1.D23-D36

\section{Article info}

Received 11 April 2021

Accepted 26 July 2021

Online 22 October 2021

\section{Keywords:}

bridge beam,

span,

support,

design scheme,

test load,

static tests,

deflection

ISSN $1335-4205$ (print version) ISSN 2585-7878 (online version)

\section{Introduction}

The overpass is located on a straight section in the plan and on a longitudinal slope in $i=5 \%$ profile. The longitudinal axis intersection angle of the highway overpass with the existing highway is $66^{\circ}$. The bridge layout is accepted $33+33 \mathrm{~m}$. The overpass length is taken along the rear edges of backwalls and according to the project is $66.917 \mathrm{~m}$. The overpass dimensions, taking into account the speed change lanes are taken $17.0+2 \times 1.0 \mathrm{~m}$. The roadway width is $4 \times 3.5=14.0 \mathrm{~m}$ and the safety lanes are $1.5 \mathrm{~m}$ each.

The roadway structure is taken as a two-layer one, consisting of "TECHNOELASTMOST S" waterproofing material laid on top of an overhead slab and asphalt concrete pavement with a thickness of $70 \mathrm{~mm}$.

The "MAURER" D-100 type expansion joints are arranged along the roadway width above the end and intermediate supports, within the sidewalks compensator type expansion joints. The railing is a metal safety fence with a height of $1.2 \mathrm{~m}$, the posts of which are welded to the embedded parts in the bridge construction monolithic sections.

The safety fence posts are bolted to the embedded parts installed in separate bollards. The coupling structure is made of cast-in-place and precast constructions. Prefabricated blocks grouting is performed at the ends of the transition slabs, which slabs are made of the precast reinforced concrete of a length of $8.0 \mathrm{~m}$. The overpass coupling structure with approach embankment includes the device of draining backfill behind the supports, laying of reinforced concrete transition slabs of a length of $8 \mathrm{~m}$ along the roadway entire width. The coupling of sidewalks with curbs-transition slabs is of a length of $2 \mathrm{~m}$.

The roadway and sidewalk drainage is designed according to the longitudinal scheme. The roadway transverse profile has $20 \%$ of the two sloping surfaces from the roadway axis. Atmospheric water is diverted from the overpass roadway due to the longitudinal slopes.

The overpass superstructures consist of the VTK-33u prestressed beams of a length of $33 \mathrm{~m}$. A monolithic reinforced concrete overhead slab with joint grouting on the roadway slabs of VTK-33u beams is arranged on the top of the superstructures beams (the abbreviation "VTK" is from the Russian term "BTK vysokotekhnologicheskaja konstrukcija", what means "high-tech construction" for bridges).

Fourteen beams are installed in transverse profile of the overpass superstructures. The overpass intermediate supports consist of six monolithic posts of oval profile with a width of $800 \mathrm{~mm}$, connected on top by a monolithic crossbar. The intermediate support 


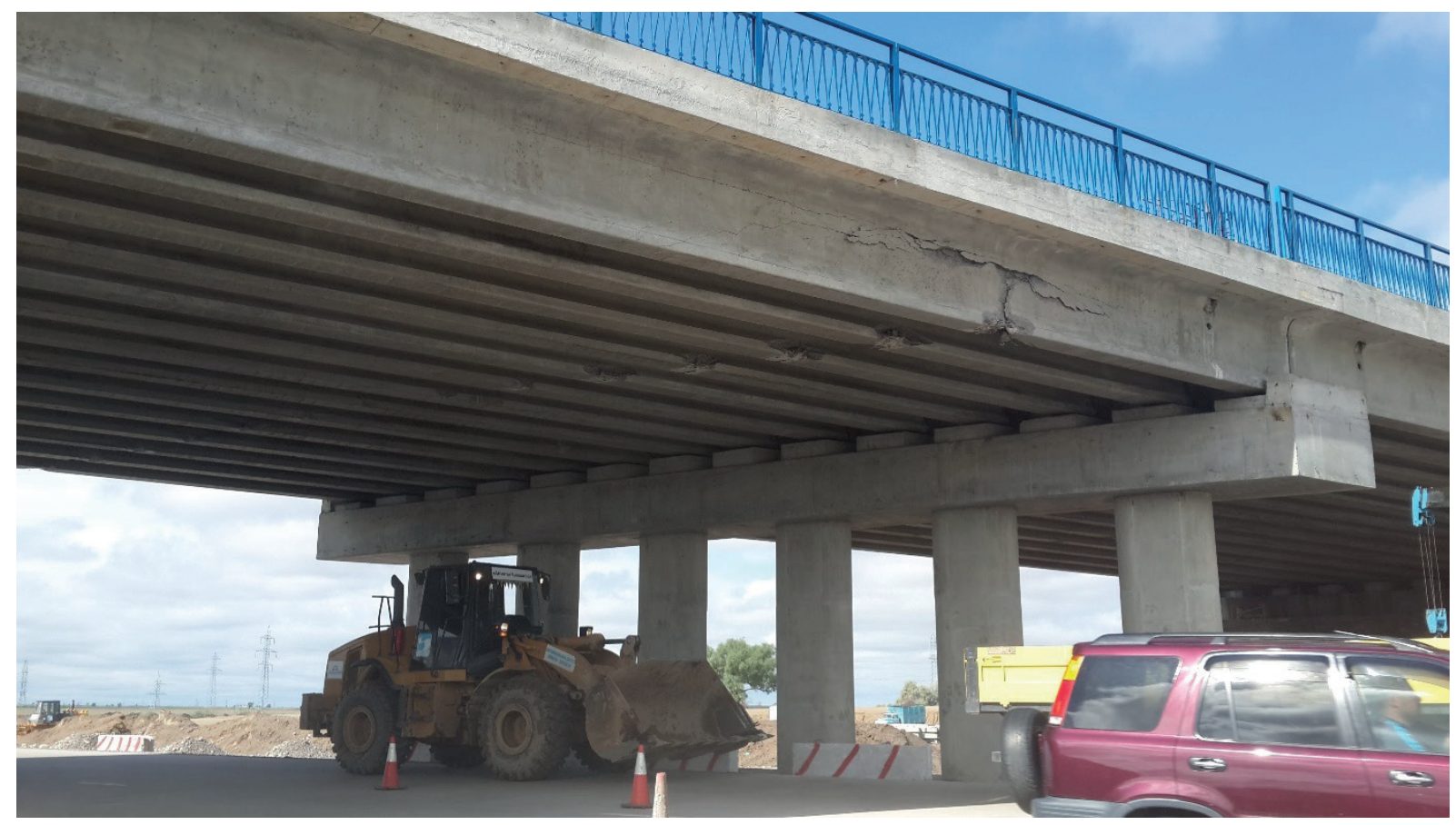

Figure 1 General view of the overpass from Kapshagai before repair

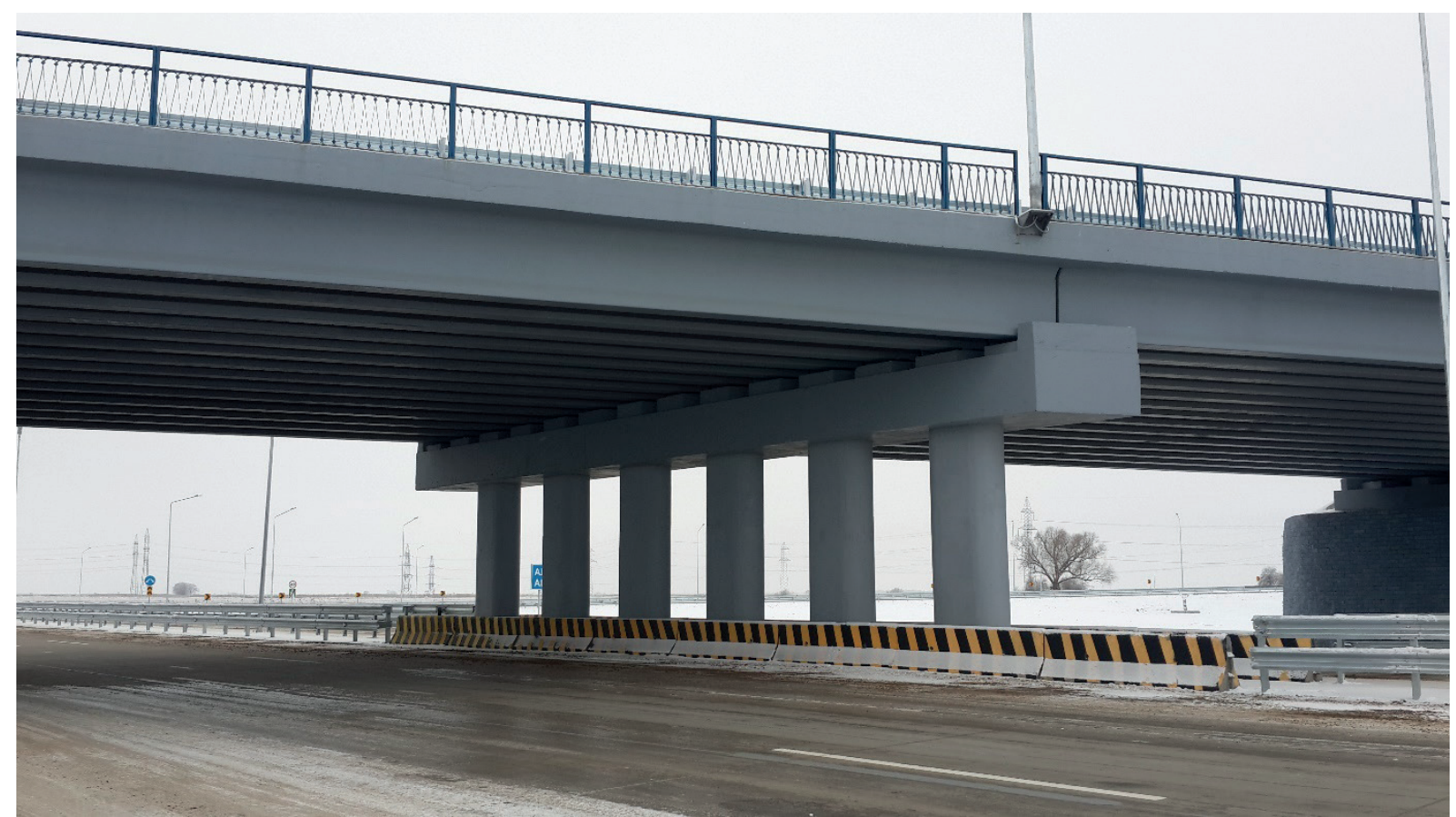

Figure 2 General view of the repaired superstructure No. 1 from Almaty

foundations are taken in the form of load distribution structures, supported by drilled piers with a diameter of $1500 \mathrm{~mm}$. The abutment foundations are also taken in the form of load distribution structures, supported by drilled piers of a diameter of $1500 \mathrm{~mm}$.

\section{Materials and methods}

The peculiarity of this structure was that during its construction, all fourteen VTK-33u beams of superstructure No. 1 were damaged as a result of vehicle impact.

Figure 1 shows a general view of the road overpass before repair and Figure 2 shows the repaired superstructure No. 1 [1].

The following types of activities have been performed [2-8] during the highway overpass survey:

- familiarization with the project documentation in terms of construction solution adopted in the project and as-built documents for construction;

- control measurements of the bridge supporting 
structures geometric parameters and their compliance with the project requirements;

- condition survey of the roadway structures, supports and superstructures;

- technical survey of the superstructures bottom beams (camber beam assessment in the middle of the superstructure) and the overpass vehicular deck top.

\section{Results and discussion}

A survey using geodetic tools was conducted to assess the position of the highway overpass elements in space.

Instrumental measurements allow to observe the vertical and horizontal deformations of superstructures and supports. Those measurements allow to timely the detect hidden defects that cannot be discovered during the inspection, help explain the appearance of defects found during the inspection, as well as choose the most correct ways to repair and strengthen the structure [9-10].

The survey was conducted under the following weather conditions: ambient temperature $-4{ }^{\circ} \mathrm{C}$, light wind, low clouds, good visibility. A technical survey of the bottom of the main beams of the reinforced concrete superstructures, to determine their camber was conducted in accordance with the work program. The technical survey was conducted at three points on each main beam - in the area of the beam support sections and in the middle of its span [11].

The technical survey results made it possible to determine some moments on each superstructures beam, results of which are shown in Table 1. As can be seen from this table, all the beams have the bending moments, with the exception of beam No. 14 in superstructure No. 1, which rests in an almost horizontal position. That is, in the longitudinal direction, the static scheme is two simple spans.
The data analysis given in Table 2 shows that the bending moments in beams No. 1, 2, 3, 4, 11, 12, 13 in superstructure No. 1, after laying the overhead slab and asphalt pavement, have an insignificant value and there is a deflection in beam No. 14 equal to $0.5 \mathrm{~mm}$.

It should be noted that the above-mentioned beams were installed to replace the dismantled beams.

Minor bending moments in these beams indicate that prestressing forces in the tensioned reinforcement were lower than in beams No. 5 to 10 .

A computational and analytical check was also performed [12-14].

The considered superstructure No. 1 is composed of fourteen VTK-33u reinforced concrete girder and diaphragm type beams. In the transverse direction, the beams are connected to monolithic joints on the loop outlets and with the use of a monolithic overhead slab with a thickness of $150 \mathrm{~mm}$, involved in the behavior with the help of vertical outlets from the beam slab. The monolithic joint width is assumed to be $0.3 \mathrm{~m}$, which corresponds to the accepted distance of $1.4 \mathrm{~m}$ between the beam axes.

Due to the fact that the superstructure is a slabtype structure, for the construction of influence lines, the transverse profile of the superstructure should be considered as a continuous beam on elastically settling supports, which are the main beams. The influence lines of pressures on beams are constructed as influence lines of beams support reactions on elastic supports [15-16].

The distance between the beams is $d=1.4 \mathrm{~m}$ and the effective span is $l=32.4 \mathrm{~m}$.

Inertia moment of a $1 \mathrm{~m}$ wide superstructure slab is:

$I_{p l}=\frac{b h_{f}^{3}}{12}=\frac{1 \cdot 0.3^{3}}{12}=2.25 \cdot 10^{-3} \mathrm{~m}^{4}$.

The inertia moment of the VTK-33u beam transverse profile, in the middle of the span with the overhead slab, according to this project, is assumed to be equal to:

Table 1 Bending moments data in the overpass superstructure beams

\begin{tabular}{ccc}
\hline \multirow{2}{*}{ Beam number } & \multicolumn{3}{c}{ Bending of beams, mm } \\
\cline { 2 - 3 } 1 & Span structure No. 1 & Span structure No. 2 \\
\hline 2 & -3.5 & -29.5 \\
3 & -4.5 & -34.0 \\
4 & -4.0 & -42.0 \\
5 & -10.0 & -34.5 \\
6 & -25.5 & -39.5 \\
7 & -29.0 & -33.5 \\
8 & -18.5 & -31.5 \\
9 & -24.0 & -29.5 \\
10 & -23.0 & -31.0 \\
11 & -30.5 & -37.5 \\
12 & -10.0 & -37.5 \\
13 & -2.0 & -40.5 \\
14 & -4.0 & -37.0 \\
\hline
\end{tabular}




$$
I_{\text {beam }}=186.6 \cdot 10^{-3} \mathrm{~m}^{4} .
$$

The stiffness parameter is:

$$
\begin{aligned}
& \alpha=12.8 \cdot \frac{d^{3}}{l^{4}} \cdot \frac{E_{b} I_{\text {beam }}}{E_{b} I_{p l}}=12.8 \cdot \frac{1.4^{3}}{32.4^{4}} \times \\
& \times \frac{186.6 \cdot 10^{-3}}{2.25 \cdot 10^{-3}}=0.00264 .
\end{aligned}
$$

The pressure influence line ordinates on the elastically settling supports were found according to formulas for an eight-span beam with cantilevers based on the calculation data. If the number of spans of the transverse structure exceeds eight, eight spans can be taken into account, since the impact of subsequent spans is insignificant.

The calculation data of the pressure influence line ordinates, on the elastically settling supports (beams) are shown in Table 2.

The bridge superstructure was calculated for the most unfavorable load - the load from vehicles is taken in such a form that the cars of the prescribed weight were placed in two lanes, shifted to the edge of the bridge travelled way (including the safety lanes), to determine

\begin{tabular}{|c|c|c|c|c|c|c|c|}
\hline \multirow{2}{*}{$\begin{array}{l}\text { The number } \\
\text { of the beam in } \\
\text { the transverse } \\
\text { direction }\end{array}$} & \multicolumn{7}{|c|}{ Ordinates of the lines of influence of pressure on the supports } \\
\hline & $\mathrm{R} 1$ & $\mathrm{R} 2$ & R3 & $\mathrm{R} 4$ & R5 & R6 & R7 \\
\hline 1 & 0.426 & 0.323 & 0.228 & 0.146 & 0.077 & & \\
\hline 2 & 0.323 & 0.268 & 0.209 & 0.152 & 0.099 & 0.077 & \\
\hline 3 & 0.228 & 0.209 & 0.187 & 0.155 & 0.119 & 0.099 & 0.077 \\
\hline 4 & 0.146 & 0.152 & 0.155 & 0.151 & 0.134 & 0.119 & 0.099 \\
\hline 5 & 0.077 & 0.099 & 0.119 & 0.134 & 0.141 & 0.134 & 0.119 \\
\hline 6 & 0.020 & 0.051 & 0.081 & 0.110 & 0.134 & 0.141 & 0.134 \\
\hline 7 & -0.030 & 0.007 & 0.044 & 0.081 & 0.119 & 0.134 & 0.141 \\
\hline 8 & -0.074 & -0.034 & 0.007 & 0.051 & 0.099 & 0.119 & 0.134 \\
\hline 9 & -0.116 & -0.074 & -0.030 & 0.020 & 0.077 & 0.099 & 0.119 \\
\hline 10 & & & & & & 0.077 & 0.099 \\
\hline 11 & & & & & & & 0.077 \\
\hline 12 & & & & & & & \\
\hline 13 & & & & & & & \\
\hline 14 & & & & & & & \\
\hline
\end{tabular}
the forces in the beams from the temporary prescribed

Table 2 Data on the influence line ordinates

\begin{tabular}{|c|c|c|c|c|c|c|c|c|c|c|}
\hline \multirow{3}{*}{$\begin{array}{l}\text { Beam } \\
\text { No. }\end{array}$} & \multicolumn{2}{|c|}{$\begin{array}{c}\text { Transverse location } \\
\text { factor }\end{array}$} & \multicolumn{2}{|c|}{ Design load } & \multicolumn{2}{|c|}{ Load safety factor } & \multirow{3}{*}{$\begin{array}{l}\text { Dynamic } \\
\text { coefficient }\end{array}$} & \multirow{3}{*}{$\begin{array}{c}\text { Influence } \\
\text { line area } \\
\mathrm{m}^{2}\end{array}$} & \multicolumn{2}{|c|}{$\begin{array}{l}\text { Calculated bending } \\
\text { moments in the middle } \\
\text { of the beam span }\end{array}$} \\
\hline & \multirow[t]{2}{*}{$\begin{array}{l}\text { for load } \\
\text { trolley }\end{array}$} & \multirow{2}{*}{$\begin{array}{l}\text { for } \\
\text { intended } \\
\text { load }\end{array}$} & $\begin{array}{c}\text { for load } \\
\text { trolley }\end{array}$ & $\begin{array}{l}\text { for } \\
\text { intended } \\
\text { load }\end{array}$ & \multirow[t]{2}{*}{$\begin{array}{c}\text { for load } \\
\text { trolley }\end{array}$} & \multirow{2}{*}{$\begin{array}{l}\text { for } \\
\text { intended } \\
\text { load }\end{array}$} & & & $\begin{array}{c}\text { for } \quad \gamma_{f}>1 \\
1+\mu>1\end{array}$ & \multirow[t]{2}{*}{$\begin{array}{c}\text { for } \gamma_{f}=1 \\
1+\mu>1\end{array}$} \\
\hline & & & $\mathrm{kN}$ & $\mathrm{kN} / \mathrm{m}$ & & & & & & \\
\hline 1 & 0.378 & 0.337 & & & & & & & 1868 & $1573^{*}$ \\
\hline 2 & 0.356 & 0.309 & & & & & & & 1739 & $1464^{*}$ \\
\hline 3 & 0.330 & 0.277 & & & & & & & 1590 & $1339 *$ \\
\hline 4 & 0.294 & 0.238 & 140 & 14 & $\frac{1.178}{1.0}$ & $\frac{1.2}{1.0}$ & 1.095 & 131.2 & 1395 & $1175^{*}$ \\
\hline 5 & 0.248 & 0.204 & & & & & & & 1185 & $998^{*}$ \\
\hline 6 & 0.217 & 0.182 & & & & & & & 1044 & $880^{*}$ \\
\hline 7 & 0.178 & 0.152 & & & & & & & 863 & $727^{*}$ \\
\hline
\end{tabular}

Table 3 Data used for calculation and values of bending moments

* Values of the bending moments in the middle of the beam span with a load safety factor of one $\left(\gamma_{f}=1.0\right)$ and a full dynamic coefficient $((1+\mu)>1.0)$ 

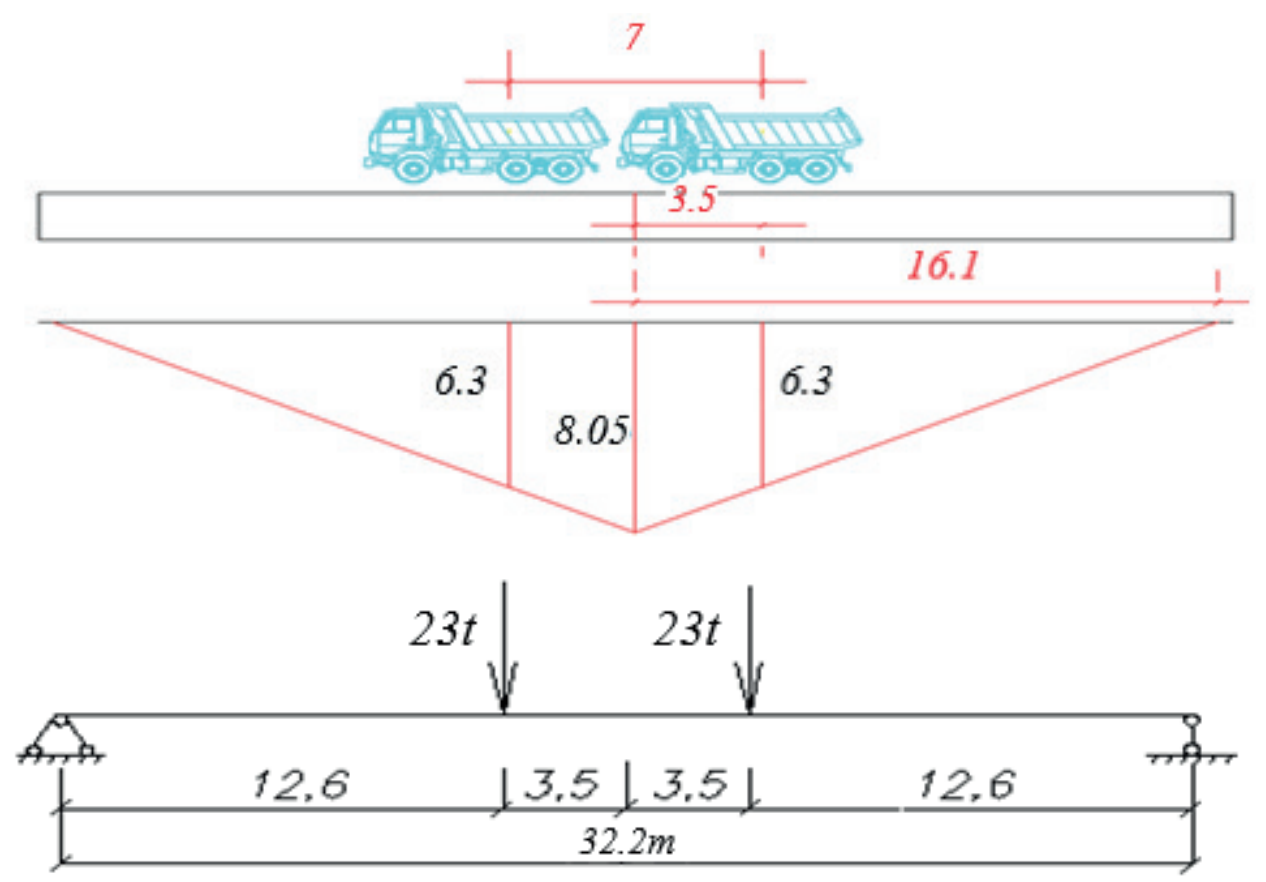

Lines of Influence $M l$

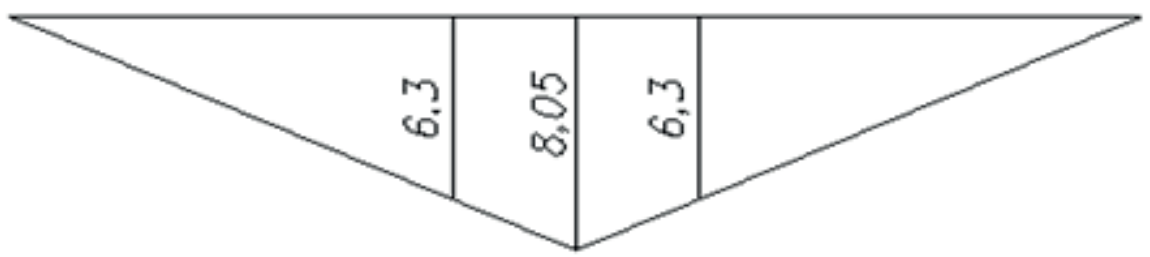

Figure 3 The influence line of the bending moment in the middle of the beam span and the position of the test load on the superstructure

Table 4 The transverse location factor (TLF) data from the action of the test load

\begin{tabular}{cccccc}
\hline \multicolumn{2}{c}{ First test stage } & \multicolumn{2}{c}{ Second test stage } & \multicolumn{2}{c}{ Third test stage } \\
\hline Beam No. & TLF & Beam No. & TLF & Beam No. & TLF \\
\hline 1 & 0.378 & 14 & 0.378 & 1 & -0.099 \\
2 & 0.356 & 13 & 0.356 & 2 & -0.025 \\
3 & 0.330 & 12 & 0.330 & 3 & 0.051 \\
4 & 0.294 & 11 & 0.294 & 4 & 0.131 \\
5 & 0.248 & 10 & 0.248 & 5 & 0.214 \\
6 & 0.217 & 9 & 0.217 & 6 & 0.245 \\
7 & 0.178 & 8 & 0.178 & 7 & 0.262 \\
\hline
\end{tabular}

load from cars. The outer track axis of the prescribed load from cars is moved from the curb edge for $0.55 \mathrm{~m}$. The distance between the lane load axes is assumed to be $3 \mathrm{~m}$. The load trolley of prescribed load from cars is installed in the middle of the superstructure No. 1.

Table 3 shows the calculation data and determined values of the bending moments in the middle of the beam span, with the load safety factor greater than one $\left(\gamma_{f}>1.0\right)$ and a full dynamic coefficient $((1+\mu)>1.0)$ and with a load safety factor of one $\left(\gamma_{f}=1.0\right)$ and a full dynamic coefficient $((1+\mu)>1.0)$.

Here is the test load calculation. The influence line of the bending moment in the middle of the beam span and the position of the test load on the superstructure are shown in Figure 3.

Table 4 shows the transverse location factor (TLF) values from the action of the test load when the last row of trucks is located at a distance of $1.5 \mathrm{~m}$ from the roadway safety fence and in the middle of the superstructure (Figures 4, 5 and 6).

The analysis of the transverse location factor values showed that at the accepted position of the test load at the first, second and third stages of the tests, the maximum load was on beams No. 1, No. 14 and No. 7, respectively.

Determined bending moments in the middle of the 


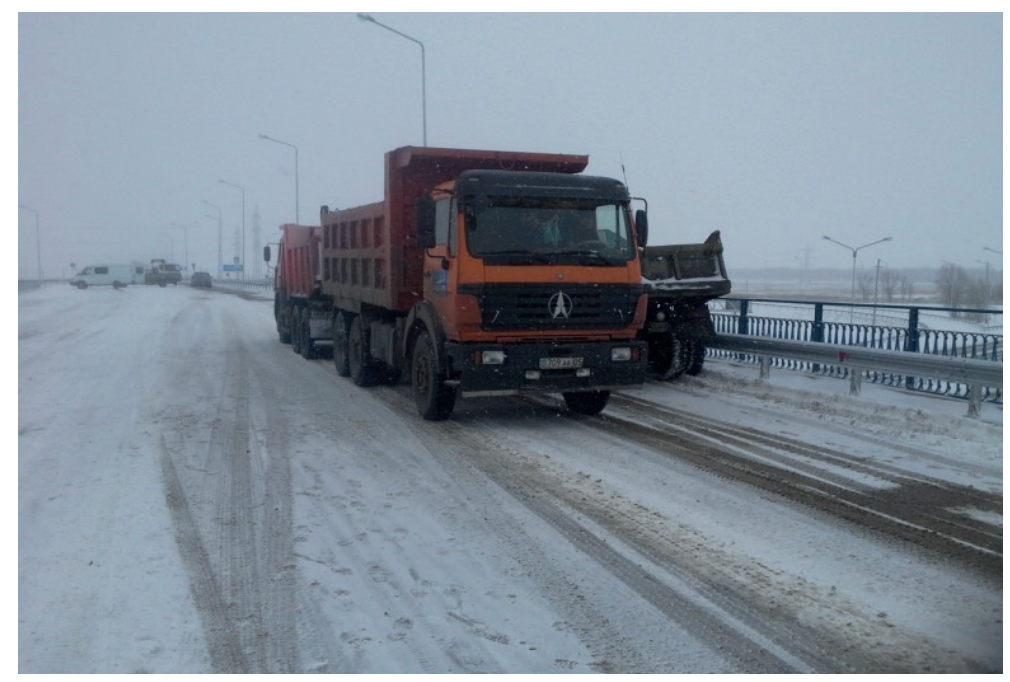

Figure 4 Vehicles are located at the roadway safety fence of superstructure No. 1 from Kapshagai at the first stage of testing

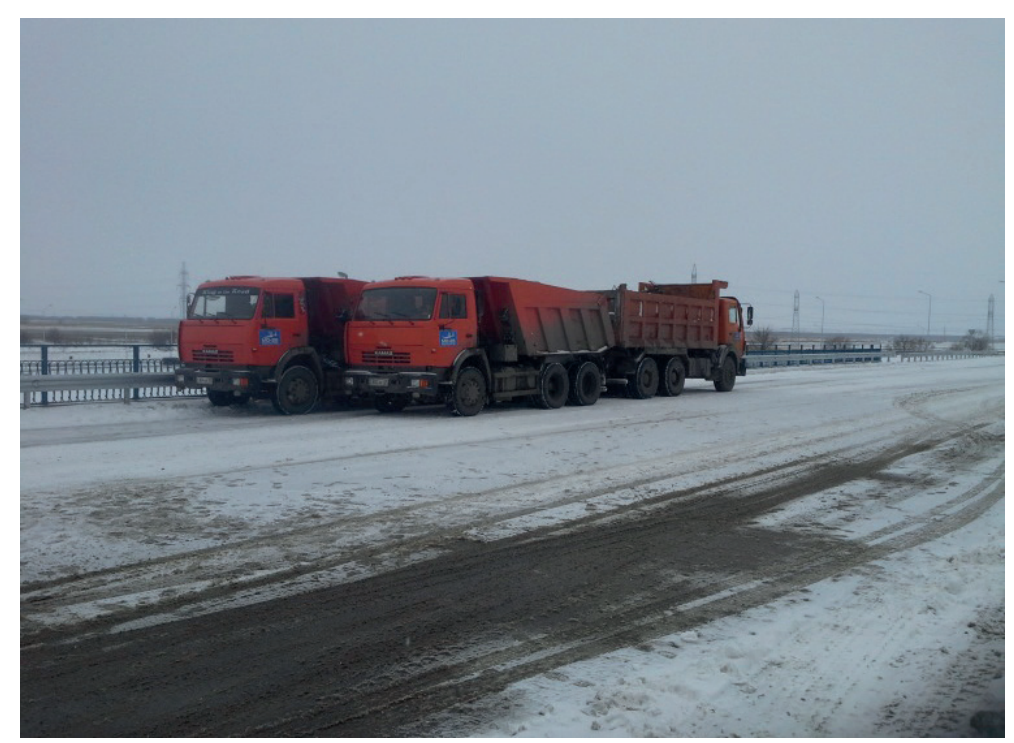

Figure 5 Vehicles are located at the roadway safety fence technical of superstructure No. 1 from Almaty at the second stage of testing

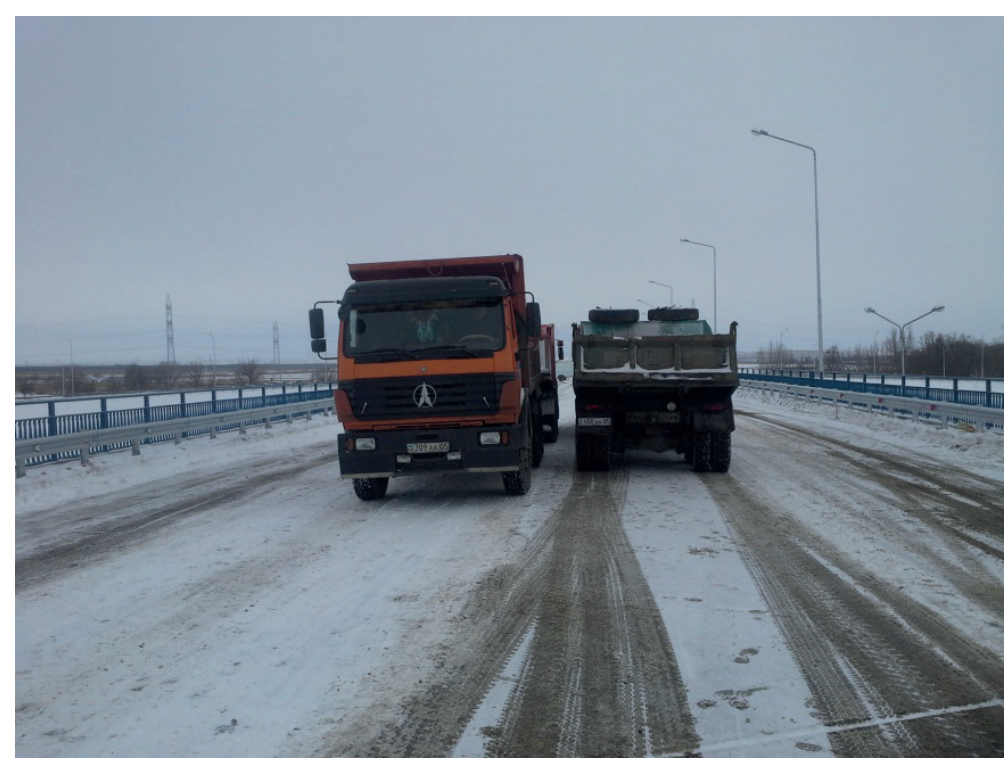

Figure 6 Vehicles are located at the longitudinal axis of superstructure No. 1 at the third stage of testing 


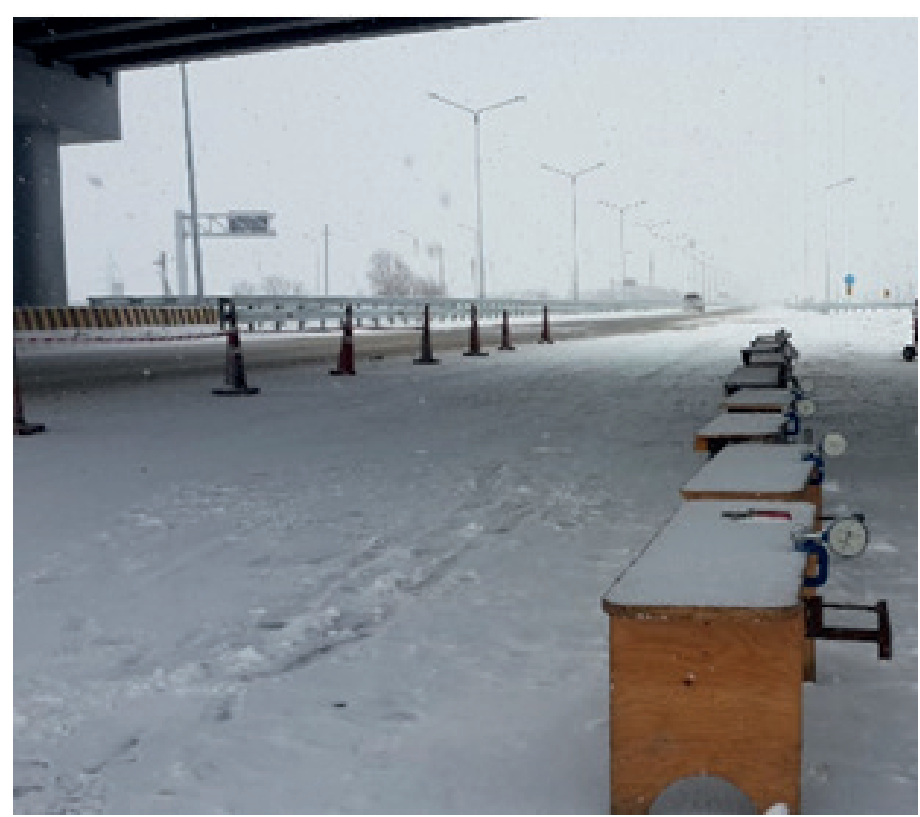

Figure 7 Location of deflection gauges under each of the fourteen beams in the middle of the superstructure No. 1
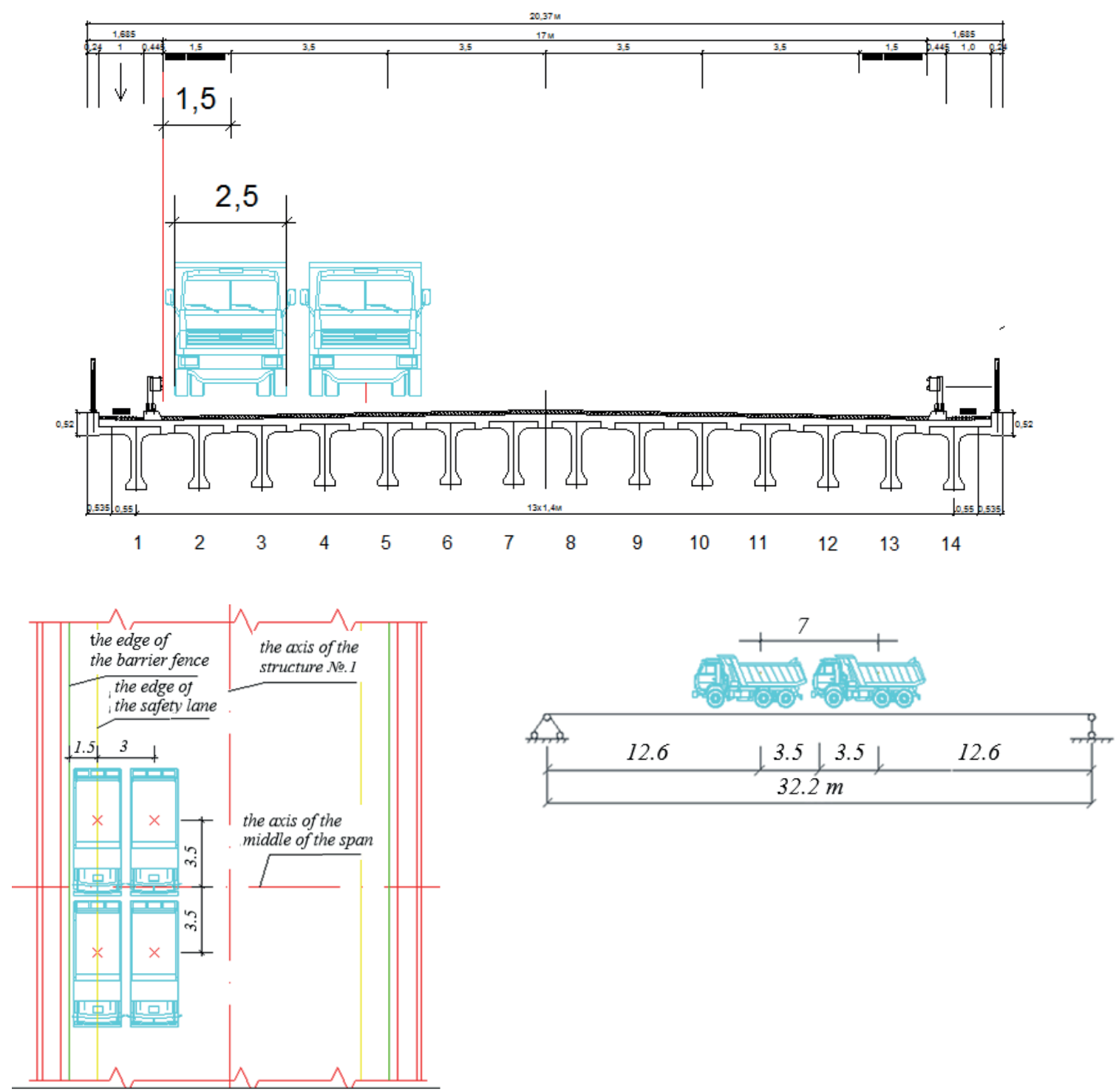

Figure 8 The first stage of the static tests on superstructure No. 1 

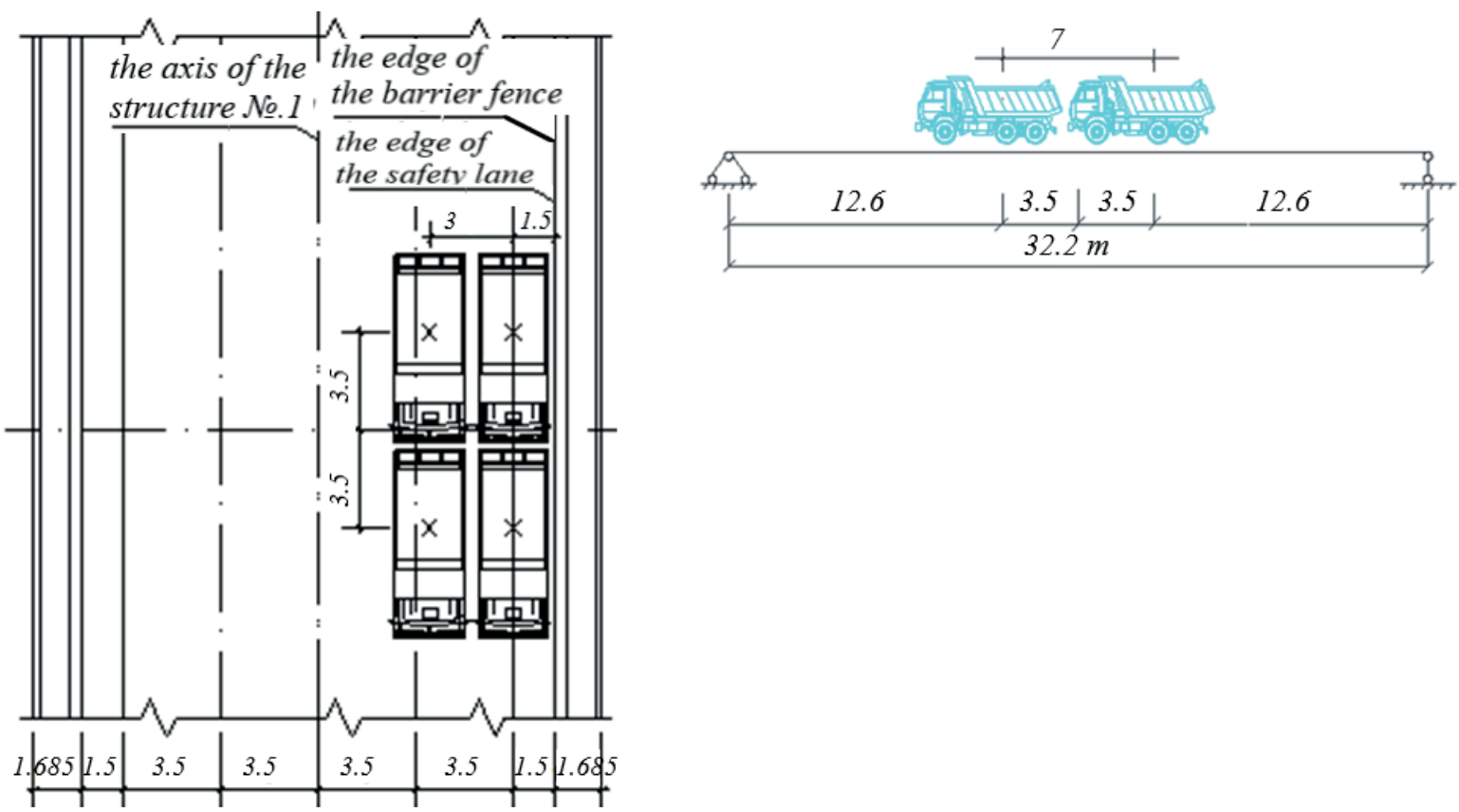

Figure 9 The second stage of the static tests on superstructure No. 1

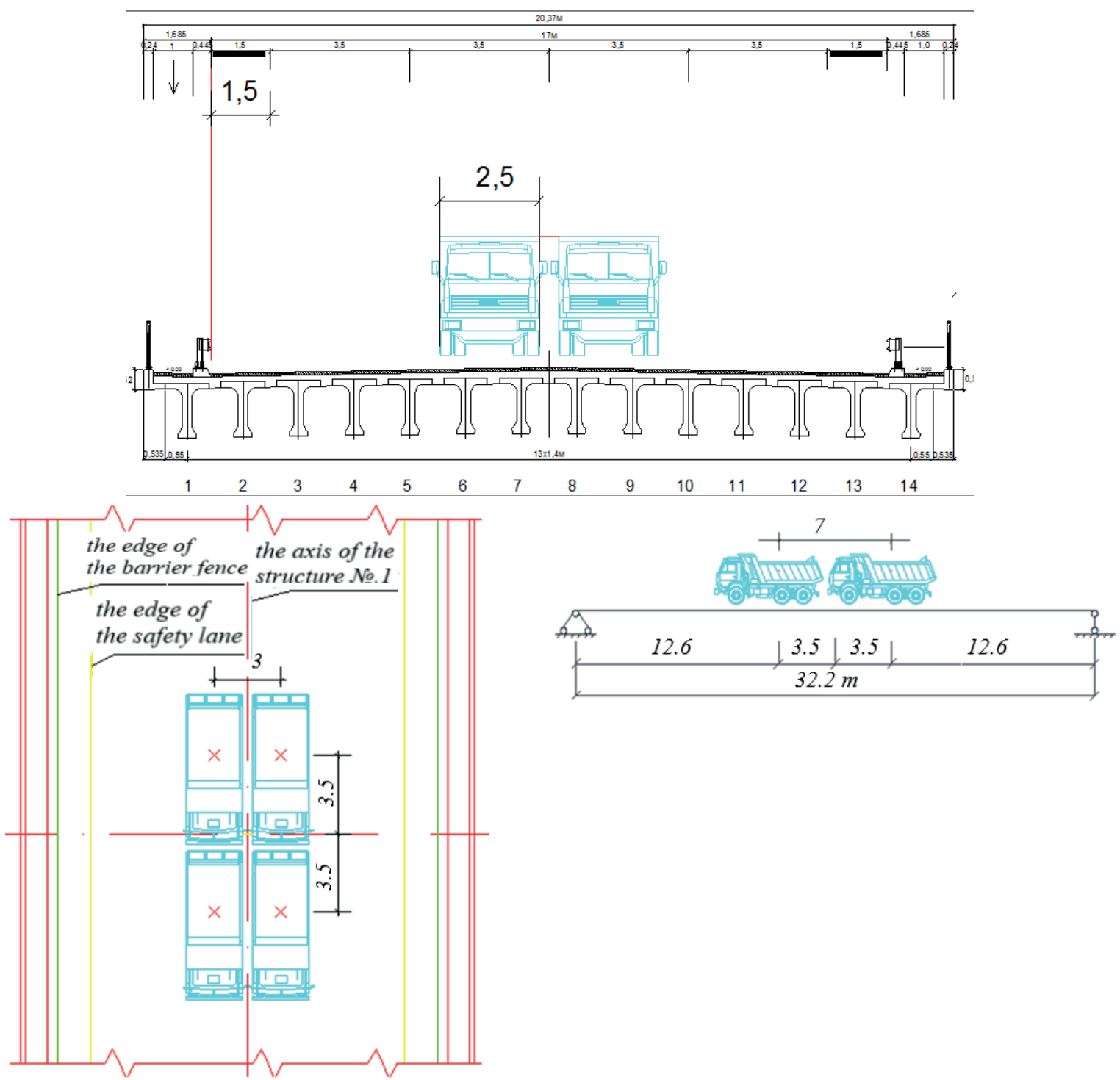

Figure 10 The third stage of the static tests on superstructure No. 1 
beam for each test stage are:

- In beams No. 1 and No. 14 for the first and second stage of testing:

$M_{(1 \text { and } 14)}=2 \cdot 23.0 \cdot 0.378 \cdot 6.34 \cdot 10=1102 \mathrm{kN} \cdot \mathrm{m}$.

- In beam No. 7 for the third stage of testing:

$M_{(7)}=2 \cdot 23.0 \cdot 0.262 \cdot 6.34 \cdot 10=764 k N \cdot m$

The force arising in highway and city bridges from the action of the test load should be in the range of 70 to $100 \%$ of the calculated forces from the action of the live temporary vertical load adopted in the project, with the load safety factor equal to one $\left(\gamma_{f}=1.0\right)$ and a full dynamic coefficient $((1+\mu)>1.0)$ in accordance with the regulatory documents of the Republic of Kazakhstan.

The calculated value of the bending moment from the action of temporary loads in the most loaded beam with the load safety factor of more than one $\left(\gamma_{f}>1.0\right)$ and a full dynamic coefficient $((1+\mu)>1.0)$ is $\mathrm{M}_{\mathrm{tl}}=1868 \mathrm{kN} \cdot \mathrm{m}$ in accordance with the calculation (see Table 4).

The permissible bending moment in the beam from the action of the temporary load with the load safety factor equal to one $\left(\gamma_{f}=1.0\right)$ and a full dynamic coefficient $((1+\mu)>1.0)$ is $M_{t l}=1573 \mathrm{kN} \cdot \mathrm{m}$.

The calculated bending moment ratio from the action of the test load to the bending moment from the action of the temporary load with the load safety factor equal to one $\left(\gamma_{f}=1.0\right)$ and a full dynamic coefficient $((1+\mu)>1.0)$ is:

For the first and second stages:

$\frac{M_{(1 \text { and } 14)}}{M_{t l}}=\frac{1102 k N \cdot m}{1573 k N \cdot m}=0.7$.

For the third stage:

$\frac{M_{(7)}}{M_{t l}}=\frac{764 k N \cdot m}{1573 k N \cdot m}=0.5$.

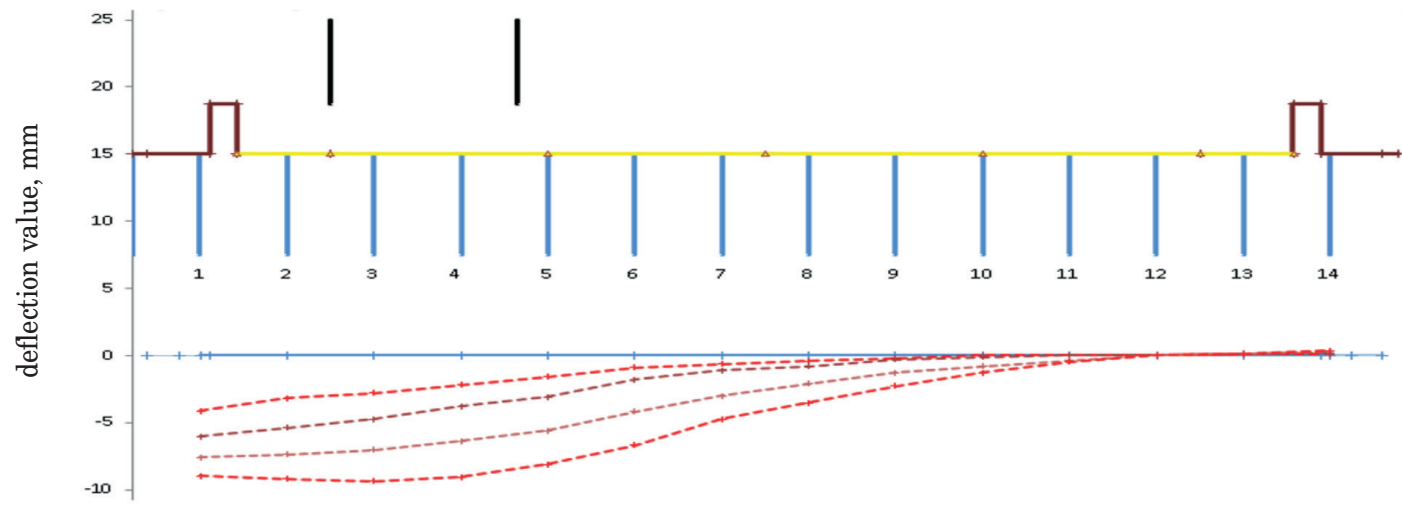

no. of beams

\begin{tabular}{|c|c|c|c|c|c|c|c|c|c|c|}
\hline \multirow{2}{*}{$\begin{array}{l}\text { Measurement } \\
\text { type }\end{array}$} & \multirow{2}{*}{$\begin{array}{l}\text { Beam } \\
\text { No. }\end{array}$} & \multirow{2}{*}{$\begin{array}{l}\text { zero } \\
\text { count }\end{array}$} & 1 stage & \multirow[t]{2}{*}{$\mathrm{f}, \mathrm{mm}$} & \multirow{2}{*}{$\begin{array}{c}2 \text { stage } \\
\text { count }\end{array}$} & \multirow{2}{*}{$\mathrm{f}, \mathrm{mm}$} & \multirow{2}{*}{$\begin{array}{c}3 \text { stage } \\
\text { count }\end{array}$} & \multirow{2}{*}{$\mathrm{f}, \mathrm{mm}$} & 4 stage & \multirow[t]{2}{*}{$\mathrm{f}, \mathrm{mm}$} \\
\hline & & & count & & & & & & count & \\
\hline Aistov & 1 & 25 & 340 & 3.15 & 628 & 6.03 & 783 & 7.58 & 925 & 9 \\
\hline Aistov & 2 & 0 & 320 & 3.2 & 538 & 5.38 & 736 & 7.36 & 920 & 9.2 \\
\hline Aistov & 3 & 47 & 325 & 2.78 & 521 & 4.74 & 752 & 7.05 & 983 & 9.36 \\
\hline Aistov & 4 & 770 & 991 & 2.21 & 1150 & 3.8 & 1409 & 6.39 & 1676 & 9.06 \\
\hline CRIBS & 5 & 3 & 19 & 1.6 & 34 & 3.1 & 59 & 5.6 & 84 & 8.1 \\
\hline CRIBS & 6 & 0 & 9 & 0.9 & 18 & 1.8 & 42 & 4.2 & 67 & 6.7 \\
\hline Aistov & 7 & 26 & 88 & 0.62 & 136 & 1.1 & 328 & 3.02 & 502 & 4.76 \\
\hline Aistov & 8 & 12 & 53 & 0.41 & 92 & 0.8 & 223 & 2.11 & 364 & 3.52 \\
\hline CRIBS & 9 & 2 & 4 & 0.2 & 5 & 0.3 & 15 & 1.3 & 25 & 2.3 \\
\hline CRIBS & 10 & 4 & 4 & 0 & 5 & 0.1 & 12 & 0.8 & 17 & 1.3 \\
\hline Aistov & 11 & 44 & 43 & -0.01 & 44 & 0 & 82 & 0.38 & 89 & 0.45 \\
\hline Aistov & 12 & 46 & 45 & -0.01 & 44 & -0.02 & 47 & 0.01 & 47 & 0.01 \\
\hline Aistov & 13 & 23 & 12 & -0.11 & 11 & -0.12 & 11 & -0.12 & 10 & -0.13 \\
\hline Aistov & 14 & 36 & 25 & -0.11 & 18 & -0.18 & 5 & -0.31 & 0 & -0.36 \\
\hline
\end{tabular}

Figure 11 Loading and unloading stages, the superstructure transverse profile and outline of the beam deflections during the loading and unloading at the first stage 
Four loaded vehicles with a mass of 23 tons each were accepted for the static tests, taking into account the results of this calculation.

KamAZ 65115 and North Benz ND3250S trucks with ballast, the average mass of each was mainly 23 tons, were used as the test load when conducting the static tests.

The repaired superstructure No. 1 was subjected to the control tests. Aistov and V. A. Kucherenko CRIBS deflection gauges with the price of division on the scale of the device of 0.01 and $0.1 \mathrm{~mm}$, respectively, were used to determine the deflections in fourteen beams of superstructure No. 1. The superstructure No. 1 was loaded in stages and beams deflections [17-18] were recorded at each stage of loading.

Figure 7 shows the deflection gauges' location under fourteen beams in the middle of the superstructure No. 1 .

The static tests of the overpass were conducted in accordance with the work program in three stages [19-21].
Four vehicles were installed in stages on superstructure No. 1 at the first (Figure 8) and second (Figure 9) stages of the static tests. Meanwhile, the roll axis of the last vehicle was located at a distance of $1.5 \mathrm{~m}$ from the roadway fence. The distances between the vehicles in overpass transverse and longitudinal directions were $3.0 \mathrm{~m}$ and $7.0 \mathrm{~m}$, respectively.

Four trucks - two vehicles in one row were also installed on superstructure No. 1 at the third stage of testing. The axes of each vehicle row were separated from the roadway longitudinal axis at a distance of $1.5 \mathrm{~m}$. The distances between vehicles in the overpass transverse and longitudinal directions were $3.0 \mathrm{~m}$ and $7.0 \mathrm{~m}$, respectively (Figure 10).

Experimental deflections have been determined in fourteen beams of a length of $33.0 \mathrm{~m}$ in the middle of the repaired superstructure No. 1 , according to the static tests results.

Figures 11, 12 and 13 show the loading and

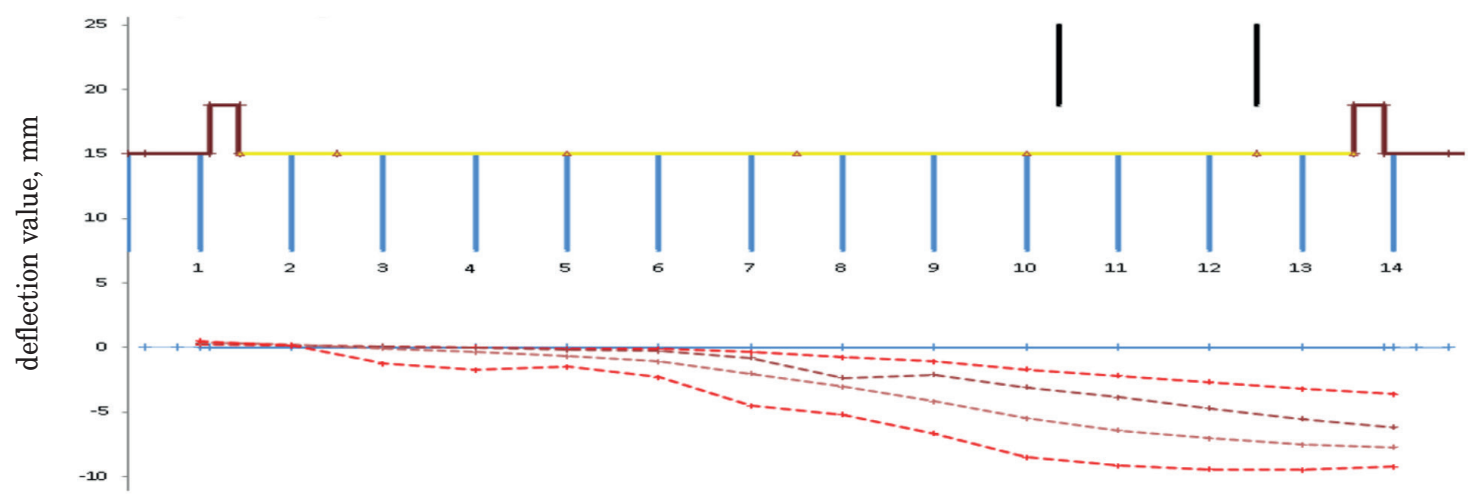

no. of beams

\begin{tabular}{|c|c|c|c|c|c|c|c|c|c|c|}
\hline \multirow{2}{*}{$\begin{array}{l}\text { Measurement } \\
\text { type }\end{array}$} & \multirow{2}{*}{$\begin{array}{l}\text { Beam } \\
\text { No. }\end{array}$} & \multirow{2}{*}{$\begin{array}{l}\text { zero } \\
\text { count }\end{array}$} & 1 stage & \multirow[t]{2}{*}{$\mathrm{f}, \mathrm{mm}$} & 2 stage & \multirow{2}{*}{$\mathrm{f}, \mathrm{mm}$} & 3 stage & \multirow{2}{*}{$\mathrm{f}, \mathrm{mm}$} & 4 stage & \multirow[t]{2}{*}{$\mathrm{f}, \mathrm{mm}$} \\
\hline & & & count & & count & & count & & count & \\
\hline Aistov & 1 & 57 & 36 & -0.21 & 27 & -0.3 & 20 & -0.37 & 9 & -0.48 \\
\hline Aistov & 2 & 21 & 10 & -0.11 & 4 & -0.17 & 2 & -0.19 & 5 & -0.16 \\
\hline Aistov & 3 & 71 & 64 & -0.07 & 62 & -0.09 & 78 & 0.07 & 197 & 1.26 \\
\hline Aistov & 4 & 785 & 786 & 0.01 & 787 & 0.02 & 821 & 0.36 & 961 & 1.76 \\
\hline CRIBS & 5 & 3 & 4 & 0.1 & 5 & 0.2 & 10 & 0.7 & 18 & 1.5 \\
\hline CRIBS & 6 & 0 & 1 & 0.1 & 3 & 0.3 & 11 & 1.1 & 23 & 2.3 \\
\hline Aistov & 7 & 25 & 61 & 0.36 & 107 & 0.82 & 228 & 2.03 & 479 & 4.54 \\
\hline Aistov & 8 & 6 & 82 & 0.76 & 243 & 2.37 & 313 & 3.07 & 528 & 5.22 \\
\hline CRIBS & 9 & 1 & 12 & 1.1 & 22 & 2.1 & 43 & 4.2 & 68 & 6.7 \\
\hline CRIBS & 10 & 2 & 19 & 1.7 & 33 & 3.1 & 57 & 5.5 & 87 & 8.5 \\
\hline Aistov & 11 & 21 & 239 & 2.18 & 406 & 3.85 & 663 & 6.42 & 940 & 9.19 \\
\hline Aistov & 12 & 25 & 292 & 2.67 & 496 & 4.71 & 729 & 7.04 & 971 & 9.46 \\
\hline Aistov & 13 & 10 & 331 & 3.21 & 564 & 5.54 & 763 & 7.53 & 958 & 9.48 \\
\hline Aistov & 14 & 31 & 393 & 3.62 & 651 & 6.2 & 806 & 7.75 & 958 & 9.27 \\
\hline
\end{tabular}

Figure 12 Loading and unloading stages, the superstructure transverse profile and outline of the beam deflections during the loading and unloading at the second stage 


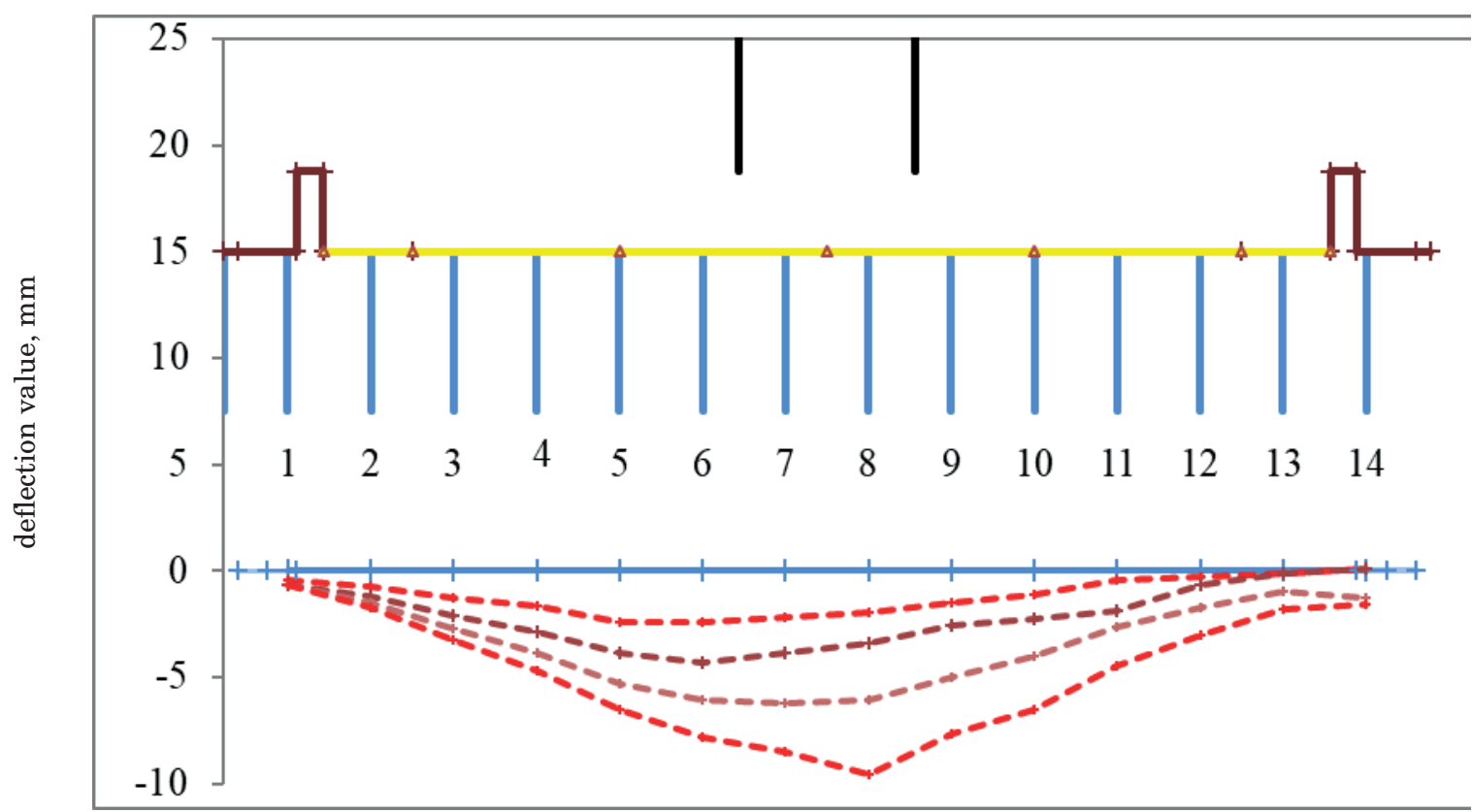

no. of beams

\begin{tabular}{|c|c|c|c|c|c|c|c|c|c|c|}
\hline \multirow{2}{*}{$\begin{array}{l}\text { Measurement } \\
\text { type }\end{array}$} & \multirow{2}{*}{$\begin{array}{l}\text { Beam } \\
\text { No. }\end{array}$} & \multirow{2}{*}{$\begin{array}{l}\text { zero } \\
\text { count }\end{array}$} & 1 stage & \multirow[t]{2}{*}{$\mathrm{f}, \mathrm{mm}$} & \multirow{2}{*}{$\begin{array}{c}2 \text { stage } \\
\text { count }\end{array}$} & \multirow{2}{*}{$\mathrm{f}, \mathrm{mm}$} & 3 stage & \multirow{2}{*}{$\mathrm{f}, \mathrm{mm}$} & 4 stage & \multirow[t]{2}{*}{$\mathrm{f}, \mathrm{mm}$} \\
\hline & & & count & & & & count & & count & \\
\hline Aistov & 1 & 51 & 92 & 0.41 & 115 & 0.64 & 120 & 0.69 & 121 & 0.7 \\
\hline Aistov & 2 & 21 & 93 & 0.72 & 139 & 1.18 & 175 & 1.54 & 198 & 1.77 \\
\hline Aistov & 3 & 64 & 191 & 1.27 & 273 & 2.09 & 337 & 2.73 & 388 & 3.24 \\
\hline Aistov & 4 & 783 & 952 & 1.69 & 1073 & 2.9 & 1168 & 3.85 & 1252 & 4.69 \\
\hline CRIBS & 5 & 3 & 27 & 2.4 & 42 & 3.9 & 56 & 5.3 & 68 & 6.5 \\
\hline CRIBS & 6 & 0 & 24 & 2.4 & 43 & 4.3 & 61 & 6.1 & 78 & 7.8 \\
\hline Aistov & 7 & 32 & 252 & 2.2 & 417 & 3.85 & 654 & 6.22 & 885 & 8.53 \\
\hline Aistov & 8 & 11 & 210 & 1.99 & 352 & 3.41 & 622 & 6.11 & 965 & 9.54 \\
\hline CRIBS & 9 & 3 & 18 & 1.5 & 29 & 2.6 & 53 & 5 & 80 & 7.7 \\
\hline CRIBS & 10 & 5 & 16 & 1.1 & 28 & 2.3 & 45 & 4 & 70 & 6.5 \\
\hline Aistov & 11 & 69 & 115 & 0.46 & 257 & 1.88 & 334 & 2.65 & 515 & 4.46 \\
\hline Aistov & 12 & 49 & 79 & 0.3 & 112 & 0.63 & 224 & 1.75 & 352 & 3.03 \\
\hline Aistov & 13 & 39 & 49 & 0.1 & 55 & 0.16 & 133 & 0.94 & 220 & 1.81 \\
\hline Aistov & 14 & 61 & 53 & -0.08 & 48 & -0.13 & 185 & 1.24 & 222 & 1.61 \\
\hline
\end{tabular}

Figure 13 Loading and unloading stages, the superstructure transverse profile and outline of the beam deflections during the loading and unloading at the third stage

unloading stages, the superstructure transverse profile and the outline of beam deflections during the loading and unloading.

At the first stage of testing, the maximum deflection value has been recorded in beam No. 3, which was $f=$ $9.36 \mathrm{~mm}$.

At the second stage of testing, the maximum deflection value has been recorded in beam No. 13 , which had a value equal to $f=9.48 \mathrm{~mm}$.

At the third stage of testing, the maximum deflection value has been recorded in beam No. 8, which had a value equal to $f=9.54 \mathrm{~mm}$.

The values analysis of the deflection increments during the loading and unloading at the first, second and third stages of the static tests testified to the elastic behavior of the VTK-33u beams of a length of $33.0 \mathrm{~m}$.

The overpass structural elements have been inspected prior to the static tests, as well as after their completion, which allowed to assess the impact of the tests on the bridge. The inspection revealed the absence of any damage in the load-bearing structures caused by the action of the test load. 
Table 5 Results of the static tests

\begin{tabular}{cccccc}
\hline Static test stage & $\begin{array}{c}\text { No. of the beam in } \\
\text { which the maximum } \\
\text { deflection is recorded }\end{array}$ & $\begin{array}{c}\text { Actual maximum } \\
\text { deflection value, } \\
\mathrm{f}_{\mathrm{e}}, \mathrm{mm}\end{array}$ & $\begin{array}{c}\text { Estimated maximum } \\
\text { deflection value, } \\
\mathrm{f}_{\text {cal }}, \mathrm{mm}\end{array}$ & $\mathrm{TLF}$ & Design factor, $\mathrm{K}$ \\
\hline 1 & 3 & 9.36 & 54.3 & 0.330 & 0.5 \\
2 & 13 & 9.48 & 0.356 & 0.5 \\
3 & 8 & 9.54 & 0.262 & 0.7 \\
\hline
\end{tabular}

The main criterion for the positive behavior of the overpass superstructures during the bridge acceptance static tests is the compliance of the beams elastic deflections measured under the influence of the test load with the deflection values determined by calculation from the action of the same test load [22-24].

Such indicator of the superstructure beam behavior during the static tests is the design factor determined by the formula:

$$
K=\frac{f_{e}}{f_{c a l}},
$$

where:

$f_{e}$ is deflection in the beam measured under the test load; $f_{c a l}$ - deflection in the beam, determined by calculation from the action of the test load.

$K$ - design factor values for the main load-bearing structures and their elements are from 0.7 to 1.0 and for the superstructures elements, in which the calculations do not take into account the joint behavior of the main beams with the elements of the roadway and road surfacing, as a rule, from 0.5 to 0.7 according to the static tests results.

The calculated deflection from the test load action in the middle of the span of a length of $33.0 \mathrm{~m}$ is determined by the formula:

$f_{\text {cal }}=\frac{1.1 \cdot p \cdot l^{3}}{24 \cdot E_{b} \cdot I_{r e d}}$

where:

$P=230 k N$ is the truck load;

$l=32.4 m-$ calculated beam span;

$E_{b}=352 \cdot 10^{5} \mathrm{kN} / \mathrm{m}^{2}$ - beam concrete modulus of elasticity;

$I_{\text {red }}=0.1875 \mathrm{~m}^{4}$ - inertia moment of the cross section in the middle of the beam.

Its behavior as a part of the superstructure should

be taken into account when determining the deflection in a beam. The test load proportion perceived by the beam is determined by the transverse location factor shown in Table 5 .

The obtained design factor values indicate presence of load-bearing capacity reserves in the structural elements and evidence that the superstructure beams behavior corresponds to the accepted microflexibility approach.

\section{Conclusions}

Based on the survey results of damaged structures, the recommendations for the repair of some beams have been developed and a number of beams have been proposed to be dismantled and replaced by the new beams.

Defects that reduce the structure operational properties were not detected during the survey. The technical condition of the structural elements and, in general, the structure itself should be recognized as meeting the project requirements.

The overpass structures condition survey showed that there were no defects or damages affecting the safe movement of vehicles and pedestrians. The condition of the bridge load-bearing structures meets the project requirements.

Analysis of the deflection increments values, at the loading and unloading stages, in three test stages testified to the elastic behavior of the superstructure.

The survey and tests' results of Almaty-Kapshagai highway overpass showed that the actual stress-strain state of the load-bearing structures corresponds to the microflexibility approach.

The overpass design capacity $(\mathrm{km} 38+90)$ on AlmatyKapshagai highway section is provided and it can be operated under A14, NK-120 and NK-180 [25] design loads without restrictions.

\section{References}

[1] SIDDIKA, A., MAMUN, A., ALYOUSEF, R., AMRAN, M. Strengthening of reinforced concrete beams by using fiber-reinforced polymer composites: a review. Journal of Building Engineering [online]. 2019, 25, p. 24-28 [accessed 2019-10-05]. ISSN 2352-7102. Available from: https://doi.org/10.1016/j.jobe.2019.100798

[2] GOKHAN, D., NACI, C., ALPER, I., CEMAL, Y. Residual load bearing capacity and failure mechanism of impacted high-strength reinforced concrete shear beams. Engineering Failure Analysis [online]. 2021, 121, p. 24-29 [accessed 2020-31-12]. ISSN 1350-6307. Available from: https://doi.org/10.1016/j.engfailanal.2020.105185 
[3] MISKIEWICZ, M., BRUSKI D., CHROSCIELEWSKI, J., WILDE, K. Safety assessment of a concrete viaduct damaged by vehicle impact and an evaluation of the repair. Engineering Failure Analysis [online]. 2019, 106, p. 45-49 [accessed 2019-23-08]. ISSN 1350-6307. Available from: https://doi.org/10.1016/j.engfailanal.2019.104147

[4] WEI, F., YANG, S., CANCAN, Y., WENBIAO, S. YANG, H. Assessing the response and fragility of concrete bridges under multi-hazard effect of vessel impact and corrosion. Engineering Structures [online]. 2020, 225, p. 54-69 [accessed 2020-15-12]. ISSN 0141-0296. Available from: https://doi.org/10.1016/j.engstruct.2020.111279

[5] ZEIN, S., NEAZ, S., ALEX, R., ABHEEK, B. Damage assessment of GFRP bar reinforced ultra-high-strength concrete beams under overloading impact conditions. Engineering Structures [online]. 2020, 213, p. 54-69 [accessed 2020-15-06]. ISSN 0141-0296. Available from: https://doi.org/10.1016/j.engstruct.2020.110581

[6] CHASSIAKOS, A. P., VAGIOTAS, P., THEODORAKOPOULOS, D. D. A knowledge-based system for maintenance planning of highway concrete bridges. Advances in Engineering Software [online]. 2005, 36(11-12), p. 740-749 [accessed 2005-11-12]. ISSN 0965-9978. Available from: https://doi.org/10.1016/j.advengsoft.2005.03.020

[7] MAHMOUD, D., MANSOUR, M., MAHDI, I., HUSSEIN, A., ARAFAT, H. An assessment model for identifying maintenance priorities strategy for bridges. Ain Shams Engineering Journal [online]. 2019, 10(4), p. 695-704 [accessed 2019-23-08]. ISSN 2090-4479. Available from: https://doi.org/10.1016/j.asej.2019.06.003

[8] TELES, D., OLIVEIRA, M., AMORIM, D. A simplified lumped damage model for reinforced concrete beams under impact loads. Engineering Structures [online]. 2019, 205, 110070 [accessed 2019-9-12]. ISSN 0141-0296. Available from: https://doi.org/10.1016/j.engstruct.2019.110070

[9] MUSAB RABI, M., CASHELLA, K. A., SHAMASS, R. Flexural analysis and design of stainless steel reinforced concrete beams. Engineering Structures [online]. 2019, 198, 109432 [accessed 2019-14-08]. ISSN 0141-0296. Available from: https://doi.org/10.1016/j.engstruct.2019.109432

[10] YU, Y., LEE, S., CHO, J.-Y. Deflection of reinforced concrete beam under low-velocity impact loads. International Journal of Impact Engineering [online]. 2021, 154, 103878 [accessed 2021-27-03]. ISSN 0734-743X. Available from: https://doi.org/10.1016/j.ijimpeng.2021.103878

[11] KOVACIC, B., KAMNIK R., PUSTOVGAR A. Analysis of precision of geodetic instruments for investigating vertical displacement of structures. In: 15th International scientific conference Underground Urbanisation as a Prerequisite for Sustainable Development: proceedings. Procedia Engineering 165. St. Petersburg: Peter the Great St. Petersburg Polytechnic University, 2016. ISSN 1877-7058, p. 906-917.

[12] GHEITASI, A., OZBULUT, O. E., USMANI, S., ALIPOUR, M., HARRIS, D. K. Experimental and analytical vibration serviceability assessment of an in-service footbridge. Case Studies in Nondestructive Testing and Evaluation [online]. 2016, 6(A), p. 79-88 [accessed 2016-9-11]. ISSN 2214-6571. Available from: https://doi.org/10.1016/j.csndt.2016.11.001

[13] WANG, X., MAO, X., FRANGOPOL, D. M., DONG Y., WANG, H., TAO, P., QI, Z., TANG, S. Full-scale experimental and numerical investigation on the ductility, plastic redistribution and redundancy of deteriorated concrete bridges. Engineering Structures [online]. 2021, 234, p. 79-88 [accessed 2021-1-21]. ISSN 0141-0296. Available from: https://doi.org/10.1016/j.engstruct.2021.111930

[14] KRAKHMALNY, T. A., EVTUSHENKO, S. I., KRAKHMALNAYA, M. P. Improvement of a method of calculation of a residual resource of small reinforced concrete bridge constructions. In: International Conference on Industrial Engineering: proceedings. Procedia Engineering 150. Novocherkassk: Platov South-Russian State Polytechnic University, 2016. ISSN 1877-7058, p. 1797-1803.

[15] SELIEM, H. M., EID, M., SHERIF, A. G. Assessment of vehicular live load and load factors for design of shortspan bridges according to the new Egyptian code. Housing and Building National Research Center [online]. 2014, 11, p. 57-67 [accessed 2014-24-02]. ISSN 1687-4048. Available from: https://doi.org/10.1016/j.hbrcj.2014.02.009

[16] FAN, W., LIU, B., HUANG, X., SUN, S. An efficient modeling method was proposed to capture both flexural and shear behaviors of RC members under impact loading. Engineering Structures [online]. 2019, 195, p. 22-50 [accessed 2019-4-06]. ISSN 0141-0296. Available from: https://doi.org/10.1016/j.engstruct.2019.05.082

[17] RAPHAELA, W., ZGHEIBA, E., CHATEAUNEUFB, A. Experimental investigations and sensitivity analysis to explain the large creep of concrete deformations in the bridge of Chevire. Case Studies in Construction Materials [online]. 2018, 9, p. 22-30 [accessed 2018-17-05]. ISSN 2214-5095. Available from: https://doi.org/10.1016/j. cscm.2018.e00176

[18] ALAYLIOGLU, H., ALAYLIOGLU, A. Dynamic structural assessment of a highway bridge via hybrid FE model and in situ testing. Computers and Structures [online]. 1997, 63(3), p. 439-453 [accessed 1997-1-05]. ISSN 0045-7949. Available from: https://doi.org/10.1016/S0045-7949(96)00364-1

[19] HENG, K., LI, R., LI, Z., WU, H. Dynamic responses of highway bridge subjected to heavy truck impact. Engineering Structures [online]. 2021, 232, p. 22-30 [accessed 2021-1-04]. ISSN 0141-0296. Available from: https://doi.org/10.1016/j.engstruct.2020.111828 
[20] FAN, W., SHEN, D., HUANG, X., SUN, Y. Reinforced concrete bridge structures under barge impacts: FE modeling, dynamic behaviorsand UHPFRC-based strengthening. Ocean Engineering [online]. 2020, 216, p. 22-30 [accessed 2020-15-11]. ISSN 0029-8018. Available from: https://doi.org/10.1016/j.oceaneng.2020.108116

[21] GANESH, P., MURTHY, A. R. Fatigue performance of damaged RC beams rehabilitated with GGBS based ultra high performance concrete. International Journal of Fatigue [online]. 2020, 138, p. 22-30 [accessed 2020-17-05]. ISSN 0142-1123. Available from: https://doi.org/10.1016/j.ijfatigue.2020.105707

[22] VICAN, J., GOGAL, J., ODROBINAK, J., MORAVCIK, M., KOTES, P. Determination of railway bridges loading capacity. In: XXIV R-S-P Seminar, Theoretical Foundation of Civil Engineering (24RSP): proceedings. Procedia Engineering 111. Zilina: University of Zilina, 2015. ISBN 1877-7058, p. 839-844.

[23] SOUSA, H. BENTO, J., FIGUEIRAS, J. Construction assessment and long-term prediction of prestressed concrete bridges based on monitoring data. Engineering Structures [online]. 2013, 52, p. 26-37 [accessed 2013-07]. ISSN 0141-0296. Available from: https://doi.org/10.1016/j.engstruct.2013.02.003

[24] SIWOWSKI, T., RAJCHEL, M., KULPA, M. Design and field evaluation of a hybrid FRP composite - lightweight concrete road bridge. Composite Structures [online]. 2019, 230, p. 26-37 [accessed 2019-24-09]. ISSN 0263-8223. Available from: https://doi.org/10.1016/j.compstruct.2019.111504

[25] SNIP 3.06.07-86. Overpasses and underpasses. Inspection and testing requirements / Mosty i Truby. Pravila obsledovanii i ispytanii (in Kazakh). 